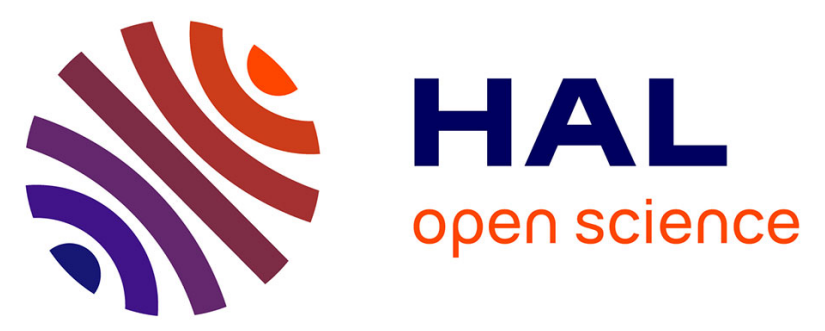

\title{
Effect of a two-week treatment with low dose of ortho-substituted polychlorinated biphenyls (PCB104 and PCB153) on VEGF-receptor system expression in the choroid plexus in adult ewes
}

\author{
Aleksandra Szczepkowska, Jaroslaw Mlynarczuk, Adam Grochowalski, \\ Laurence Dufourny, Jean-Claude Thiéry, Janina Skipor
}

\section{To cite this version:}

Aleksandra Szczepkowska, Jaroslaw Mlynarczuk, Adam Grochowalski, Laurence Dufourny, JeanClaude Thiéry, et al.. Effect of a two-week treatment with low dose of ortho-substituted polychlorinated biphenyls (PCB104 and PCB153) on VEGF-receptor system expression in the choroid plexus in adult ewes. Polish Journal of Veterinary Sciences, 2012, 15 (4), pp.621 - 628. 10.2478/v10181-0120098-z . hal-01129694

\author{
HAL Id: hal-01129694 \\ https://hal.science/hal-01129694
}

Submitted on 29 May 2020

HAL is a multi-disciplinary open access archive for the deposit and dissemination of scientific research documents, whether they are published or not. The documents may come from teaching and research institutions in France or abroad, or from public or private research centers.
L'archive ouverte pluridisciplinaire HAL, est destinée au dépôt et à la diffusion de documents scientifiques de niveau recherche, publiés ou non, émanant des établissements d'enseignement et de recherche français ou étrangers, des laboratoires publics ou privés. 


\title{
Effect of a two-week treatment with low dose of ortho-substituted polychlorinated biphenyls (PCB104 and PCB153) on VEGF-receptor system expression in the choroid plexus in adult ewes
}

\author{
A. Szczepkowska ${ }^{1}$, J. Młynarczuk ${ }^{1}$, A. Grochowalski² ${ }^{2}$ L. Dufourny ${ }^{3}$, \\ J.-C. Thiéry ${ }^{3}$, J. Skipor ${ }^{1}$ \\ ${ }^{1}$ Institute of Animal Reproduction and Food Research, Polish Academy of Sciences, \\ Tuwima 10, 10-747 Olsztyn, Poland \\ ${ }^{2}$ Laboratory for Trace Organic Analyses of Krakow University of Technology, Poland \\ ${ }^{3}$ UMR 7247, INRA-CNRS-Universite F. Rabelais-IFCE, 37380 Nouzilly, France
}

\begin{abstract}
Ortho-substituted polychlorinated biphenyl (PCB) congeners, which constitute a large part of PCB residues found in the environment and in animal tissues, are known to exert potent vascular effects and can activate endothelial cells in the periphery and in the brain. The choroid plexus (CP) is responsible for cerebrospinal fluid (CSF) production and its epithelial cell layer is responsible for structure and functions of the blood-CSF barrier. The aims of this study were: 1) to investigate if environmentally relevant doses of PCB153 and similar doses of PCB104 caused changes in the expression of vascular endothelial growth factor (VEGF) - receptor system, which maintains CP function, and 2) to determine the level of both congeners in blood plasma after their oral administration. Studies of both congeners were performed on ovariectomized ewes treated per os with low doses $(0.1 \mathrm{mg} / \mathrm{kg}$, three times a week for two weeks) of PCB153 $(\mathrm{n}=4)$ or PCB104 $(\mathrm{n}=4)$ and vehicle (control, $\mathrm{n}=4$ ). The effects of PCB153 and PCB104 treatment on mRNA expression of two isoforms of VEGF ( $\mathrm{VEGF}_{120}$ and $\mathrm{VEGF}_{164}$ ) and their receptors Flt-1 and KDR were determined using real-time PCR. Plasma concentration of PCBs was measured using high resolution chromatography/tandem mass spectrometry (HRGC/MS-MS). We observed that neither PCB153 nor PCB104 significantly altered the mRNA of the VEGF-receptor system in the CP. In PCB treated animals plasma concentration of PCB153 $(1.425 \pm 0.16 \mathrm{ng} / \mathrm{g}$ of dry mass, DM) was about 150 times higher than PCB104 $(0.009 \pm 0.007 \mathrm{ng} / \mathrm{g}$ DM). In control animals the PCB153 level was 0.14 $\pm 0.031 \mathrm{ng} / \mathrm{g} \mathrm{DM}$, while the PCB104 level was below detection level. This indicates that increase in plasma PCB153 concentration to levels similar to those reported in humans and of PCB104 concentration to levels 100 times higher than those found in human plasma did not affect the VEGF-receptor system in the CP in adult ewes. The significantly lower increase of PCB104 than PCB153 concentration in blood after oral administration suggests different absorption of both congeners from the digestive tract.
\end{abstract}

Key words: polychlorinated biphenyls: PCB104, PCB153, vascular endothelial growth factor, choroid plexus, ewes 


\section{Introduction}

Polychlorinated biphenyls (PCBs) are chemicals that comprise a group of 209 congeners with varying degrees of chlorination, which determines their physical, chemical, and biological properties (Safe 1994). From a structural point of view, there are at least two distinct classes of PCBs: the non-ortho (coplanar) and ortho-substituted (planar) congeners. Ortho-substituted PCBs constitute a large part of the PCB residue found in the environment and animal tissues (Kodavanti et al. 1998, Faroon et al. 2001, Costera et al. 2006). The most environmentally relevant ortho-substituted PCB - 2,2',4,4',5,5'-hexachlorobiphenyl (PCB153) has been demonstrated to affect the reproductive function and puberty onset in young goats which were natally exposed to a low dose of PCB153 (Lyche et al. 2004, Oskam et al. 2005). We recently demonstrated that a low dose of PCB153 affects gonadotropin secretion in adult female ewes through an action on both pituitary Luteinizing Hormone (LH) release and the hypothalamic Gonadotropin Releasing Hormone (GnRH) pulse generator (Skipor et al. 2012). Although the brain appears to be better protected against PCBs than other tissues because of the blood-brain and blood-cerebrospinal fluid (CSF) barriers (Skipor and Thiery 2008), ortho-substituted PCBs have been reported to accumulate preferentially in the brain and CSF compared to other PCBs (Kodavanti et al. 1998, Takasuga et al. 2004, Montie et al. 2009). Recently, measurement of PCB concentration in the ovine CSF showed that PCB153 was the most abundant congener in the CSF (Skipor et al. 2012).

There is evidence that PCB153 disrupts expression of tight junction proteins in the blood-brain barrier which restricts most paracellular movement of ions and solutes across the brain barriers (Eum et al. 2008, Seelbach et al. 2010). Among ortho-substituted PCBs, 2,2',4,5,6'-pentachlorobiphenyl (PCB104) also affects tight junction proteins expression in brain endothelial cells, stimulates inflammatory mediators in vascular endothelial cells and induces prometastatic responses (Choi et al. 2003, Sipka et al. 2008). It has been demonstrated that vascular endothelial growth factor (VEGF) is involved in PCB104 induced endothelial hyperpermeability (Eum et al. 2004). VEGF is continuously and highly expressed in the choroid plexus (CP), in which the blood-CSF barrier is located (Skipor and Thiery 2008). In the ovine CP two isoforms, $\mathrm{VEGF}_{120}$ and $\mathrm{VEGF}_{164}$, are expressed (Szczepkowska et al. 2012). VEGF plays an important role in regulation of the stability of the endothelial cells in the CP (Maharaj et al. 2008) and is involved in maintaining endothelial cells' fenestrated phenotype in the CP capillaries (Roberts and Palade 1995, Esser et al. 1998). The effects of VEGF are transduced mainly by two high-affinity receptors belonging to the tyrosine kinase-family: the fms-like tyrosine kinase (Flt-1) and the fetal liver kinase-1/kinase insert domain-containing receptor (Flk-1/KDR). The CP has been shown to contain mRNA (Nico et al. 2004) and protein (Witmer et al. 2002, Maharaj et al. 2008, Yang et al. 2010) of VEGF receptors.

Studies on PCB toxicity are mainly based on in vitro models or in vitro experiments in which mice or rats are intraperitoneally injected with PCBs (Sipka et al. 2008). The in vivo effects of PCB153 and PCB104 on expression of the VEGF system in the $\mathrm{CP}$ in domestic animals exposed to PCBs through the food chain, the most common route of PCB exposure, has not yet been reported. Therefore, the aim of this study was to evaluate the effect of chronic oral administration of low doses $(0.1 \mathrm{mg} / \mathrm{kg}$ of body weight, bw) of PCB104 and PCB153 on expression of the VEGF system in the CP in ewes. Additionally, the concentration of both PCB congeners was measured in blood plasma.

\section{Materials and Methods}

\section{Animal management and experimental design}

The experiment was conducted on adult Polish Lowland ewes $(n=16,60-70 \mathrm{~kg}$ bw). To prevent variability linked with the estrous cycle or interaction with steroids the animals were ovariectomized (under xylazine anaesthesia $(0.25 \mathrm{ml} / \mathrm{kg}$, im; Rometar, Spofa, Prague, Czech Republic) about 20 days before PCB administration. All animals were maintained indoors under natural lighting conditions (OctoberNovember), each group being in separated pens in order to avoid contamination through the ingestion of PCB-contaminated faeces. The ewes were fed a diet of hay, straw, and commercial concentrates with water and mineral licks available ad libitum. Experimental procedures were conducted in accordance with the Polish Guide for the Care and Use of Animals (1997) and approved by the Local Ethics Committee (agreement no 4/2008).

After recovery, the animals were randomly allocated to three groups: group $1-$ control (control), group 2 - PCB104 treated (PCB104) and group 3 - PCB153 treated (PCB153). Animals in the PCB104 and PCB153 groups were treated with appropriate $\mathrm{PCB}$ congeners by oral gavage three times weekly for 14 days, at a dose of $0.1 \mathrm{mg} / \mathrm{kg}$ of bw. 
Table 1. Sequences of oligonucleotide primers used for Real Time - PCR analyses.

\begin{tabular}{llcc}
\hline \multicolumn{1}{c}{ Gene } & \multicolumn{1}{c}{ Primers $\left(5^{\prime} \rightarrow 3^{\prime}\right)$} & Product size & Literature source \\
\hline VEGF-A $_{120}$ & $\begin{array}{l}\text { Forward: AAGGCCAGCACATAGGAGAG } \\
\text { Reverse: CCTCGGCTTGTCACATTTT }\end{array}$ & 101bp & Kaczmarek et al. (2008) \\
\hline VEGF-A $_{164}$ & $\begin{array}{l}\text { Forward: GAGGCAAGAAAATCCCTGTG } \\
\text { Reverse: TCACATCTGCAAGTACGTTCG }\end{array}$ & 150bp & Kaczmarek et al. (2008) \\
\hline Flt-1 & $\begin{array}{l}\text { Forward: TGGATTTCAGGTGAGCTTGGA } \\
\text { VEGF receptor 1 }\end{array}$ & Reverse: TCACCGTGCAAGACAGCTTC & Redmer et al. (2005) \\
\hline $\begin{array}{l}\text { KDR } \\
\text { VEGF receptor 2 }\end{array}$ & $\begin{array}{l}\text { Forward: CTTCCAGTGGGCTGATGACC } \\
\text { Reverse: GCAACAAACGGCTTTTCATGT }\end{array}$ & $67 \mathrm{bp}$ & Redmer et al. (2005) \\
\hline $\begin{array}{l}\text { NRP-1 } \\
\text { neuropilin }\end{array}$ & $\begin{array}{l}\text { Forward: GATTGCGGTGGACGATATTAGC } \\
\text { Reverse: GGTTTTGCGCAGTCCTCTTG }\end{array}$ & $60 \mathrm{bp}$ & Vonnahme et al. (2006) \\
\hline $\begin{array}{l}\text { RPL19 } \\
\text { ribosomal protein L19 }\end{array}$ & $\begin{array}{l}\text { Forward: AATCGCCAATGCCAACTC } \\
\text { Reverse: CCCTTTCGCTTACCTATACC }\end{array}$ & 156bp & Drouilhet et al. (2010) \\
\hline $\begin{array}{l}\text { PPIC } \\
\text { peptidyl-prolyl cis- }\end{array}$ & $\begin{array}{l}\text { Forward: TGGCACTGGTGGTATAAGCA } \\
\text { Reverse: GGGCTTGGTCAAGGTGATAA }\end{array}$ & 145bp & Herman et al. (2010) \\
\hline
\end{tabular}

Animals from the control group were treated with sunflower oil used as a vehicle for PCBs. Blood samples $(20 \mathrm{ml})$ were collected from the jugular vein 15 days after beginning the PCB treatment (1 day after the end of PCB treatment) and then centrifuged and stored at $-20^{\circ} \mathrm{C}$ for further analysis of PCBs. The animals were then sacrificed and, immediately after decapitation, the brains were dissected out and the $\mathrm{CP}$ from the lateral ventricles were collected and stored at $-80^{\circ} \mathrm{C}$ until further analysis.

\section{Calculation of doses and PCB administration}

PCB104 (2,2',4,5,6'-pentachlorobiphenyl) and PCB153 (2,2',4,4',5,5'-hexachlorobiphenyl) from AccuStandard (New Haven, CT, USA) were purchased locally at Tusnovics Instruments Polska and were 99.9\% pure. Each PCB was dissolved in sunflower oil to a concentration of $1 \mathrm{mg} / \mathrm{ml}$. Literature data (Lyche et al. 2004b) indicated that similar doses of PCB153 given orally in sheep for 30 days resulted in a plasma concentration of PCB153 of $30 \mathrm{ng} / \mathrm{g}$ (wet-weight). Costera et al. (2006) demonstrated that, in goats exposed to contaminated hay (concentration of PCB153 of about $460 \mathrm{ng} / \mathrm{kg}$ of dry mass (DM)), the time to reach a steady state concentration in milk was 15 days for most PCB congeners.

\section{Relative gene expression assays}

CP tissue, frozen and cut into small pieces (20 $\mathrm{mg}$ ), was homogenized in Fenozol in Lysing Matrix D (MP Biomedicals, Illkrich, France) with a FastPrep-24 instrument (MP Biomedicals). RNA was extracted using a Total RNA Kit (A\&A Biotechnology, Poland), and Amplification Grade DNase 1 (Sigma Aldrich, Germany) was used to eliminate possible genomic DNA contamination, according to the manufacturer's instructions. The concentration and quality of RNA isolated from the CP tissue were determined using a NanoDrop (Thermo Scientific, USA) and 2\% agarose gel electrophoresis. One microgram of total RNA was retained for further use in RT (reverse transcription) reaction. The RT reaction was performed with Quanti Tect Reverse Transcription Kit according to the protocol supplied by the manufacturer (Qiagen, USA). The resulting cDNA was stored at $-20^{\circ} \mathrm{C}$ until further analysis.

To evaluate the effects of PCB treatment on mRNA expression of components of the VEGF-receptor system, real-time PCR was performed with the use of an ABI Prism 7900 sequence detection system and a Power SYBR green PCR master mix (Applied Biosystems by Life Technologies, Carlsbad, CA, USA). Specific primer pairs for the different genes were used according to the literature (Table 1). All primers were synthesized by IBB PAN (Poland). PCR-derived DNA fragments (VEGF-A ${ }_{120}$, VEGF-A ${ }_{164}$, Flt-1, KDR, NRP-1, reference genes- RPL19 and PPIC) were separated by electrophoresis on $2 \%$ agarose gels supplemented with $0.01 \%$ ethidium bromide and examined under UV light (Gel Logic100, KODAK). Each real-time PCR reaction well $(20 \mu \mathrm{l})$ contained $2 \mu$ lof diluted RT product, $0.2 \mu \mathrm{M}$ forward and reverse primers each and $10 \mu \mathrm{l}$ of Power SYBR green PCR master mix. The following protocol was used: $95^{\circ} \mathrm{C}$ for 15 min for Hot Start AmpliTaq Gold DNA polymerase and 40 cycles of $95^{\circ} \mathrm{C}$ for $10 \mathrm{~s}$ (denaturation), $55^{\circ} \mathrm{C}$ for $20 \mathrm{~s}$ (annealing), and $72^{\circ} \mathrm{C}$ for $20 \mathrm{~s}$ (extension). 

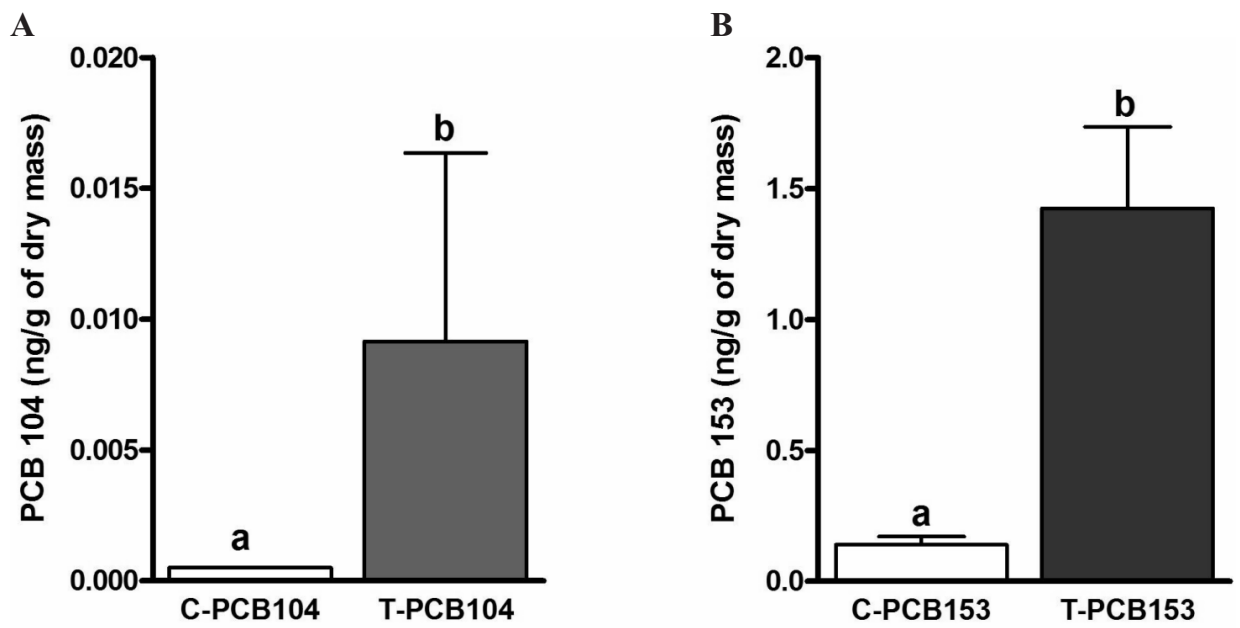

Fig. 1. Mean levels $( \pm \mathrm{SD})$ of PCB104 (A) and PCB153 (B) in blood plasma of ovariectomized ewes receiving vehicle (C-PCB104 and C-PCB153), PCB104 (T-PCB104 - A) or PCB153 (T-PCB153 - B) per os (0.1 mg/kg of body weight; 6 doses over 14 days). Note that PCB104 in control group was below detection limit.

After the cycles, a final melting curve analysis under continuous fluorescence measurement was performed to evaluate the specific amplification. The results were analyzed using Real-time PCR Miner (available on-line: http://www.miner.ewindup.info/ version2), based on the algorithm developed by Zhao and Fernald (2005).

\section{PCB determination in blood plasma}

Blood plasma samples $(20 \mathrm{ml})$ were freeze dried and spiked with clean-up standards using $1 \mathrm{ml}$ of ${ }^{13} \mathrm{C}-\mathrm{PCBs} / \mathrm{g}$ of the sample with standard mixture containing $10 \mathrm{ng} / \mathrm{ml}$ of ${ }^{13} \mathrm{C}-\mathrm{PCB} 104$ and $20 \mathrm{ng} / \mathrm{ml}$ of ${ }^{13} \mathrm{C}-\mathrm{PCB} 153$, and extracted with toluene for $16 \mathrm{~h}$ in $20 \mathrm{ml}$ Soxhlet apparatus. The extract was cleaned up according to the previously published procedure (Surma-Zadora and Grochowalski 2008). The cleaned-up extract was evaporated to approximately $1 \mathrm{ml}$, transferred to $5 \mathrm{ml}$ of dichloromethane and placed in a polyethylene semipermeable membrane. Dialysis was performed within $24 \mathrm{~h}$ with hexane as a recovery solvent. The hexane dialysate was then cleaned-up on a column which contained $10 \mathrm{~g}$ of $50 \%$ $\mathrm{H}_{2} \mathrm{SO}_{4}$ on silicagel. The column was eluted with 100 $\mathrm{ml}$ of hexane, evaporated to approximately $1 \mathrm{ml}$ and transferred to another column containing $5 \mathrm{~g}$ of acidic Alumina (Merck 101078, $0.063-0.200 \mathrm{~mm}$ of activity I) and eluted firstly with $15 \mathrm{ml}$ of hexane (fraction was discarded). The PCBs were then eluted in the second fraction of $50 \mathrm{ml}$ of $2 \%$ dichloromethane in hexane. The eluate was evaporated just to dryness and reconstituted into $50 \mu \mathrm{l}$ of nonane containing $100 \mathrm{pg} / \mathrm{ml}$ of ${ }^{13} \mathrm{C}$-1,2,3,4-tetrachlorodiben- zodioxin $\left({ }^{13} \mathrm{C}-1,2,3,4-\mathrm{TCDD}\right)$ as a precision and recovery standard.

The determination of PCBs was performed in an accredited laboratory (Laboratory for Trace Organic Analyses, Krakow University of Technology, Poland) using the isotope dilution method, high resolution chromatography/tandem mass spectrometry (HRGC/MS-MS) on a Thermo Scientific GCQ-1100/Trace2000 system adjusted to double fragmentation mode equipped with Xcalibur data acquisition and analysis software. Separation of PCB congeners was performed on a $30 \mathrm{~m} \times 0.25 \mathrm{~mm}$ i.d. DB5MS capillary column of $25 \mu \mathrm{m}$ film and DB17 $30 \mathrm{~m} \times 0.25 \mathrm{~mm}$ i.d. A sample of $2 \mu \mathrm{l}$ volume was injected into a SSL injector at $260^{\circ} \mathrm{C}$. The GC oven temperature was held at $100^{\circ} \mathrm{C}$ for 1 minute, and then raised to $180^{\circ} \mathrm{C}$ at $20^{\circ} \mathrm{C} / \mathrm{min}$, then $2^{\circ} \mathrm{C} / \mathrm{min}$ to $260^{\circ} \mathrm{C}$, and then $20^{\circ} \mathrm{C} / \mathrm{min}$ to a final temperature of $300^{\circ} \mathrm{C}$. The temperature was held at $300^{\circ} \mathrm{C}$ for 5 minutes.

The method is of high specificity and gives non-interfered signals in the determination of PCB104 and 1CB153 congeners. Recoveries of PCB104 and PCB153 were in the range of $65-90 \%$ and $85-120 \%$, respectively.

\section{Data analysis}

$\mathrm{PCB}$ data are expressed as the mean $\pm \mathrm{SD}$. The real-time PCR results are presented as the relative gene expression (mean \pm SEM) of the target gene vs. the reference gene (RPL19). The significance of differences were statistically analyzed using one-way ANOVA (PRISM 4, Graph Pad, USA). 


\section{Results}

\section{PCB determination in blood plasma}

The mean level of PCB congeners in blood plasma of sheep after oral administration of a low dose $(0.1 \mathrm{mg} / \mathrm{kg} /$ per day $)$ of PCB153 and PCB104 is presented on Fig. 1. In control sheep concentration of PCB153 was $0.14 \pm 0.031 \mathrm{ng} / \mathrm{g}$ of DM, while the PCB104 level was below the detection limit $(0.0001$ ng/g DM). After oral administration of PCB153 and PCB104, their concentrations in blood plasma were $1.425 \pm 0.16 \mathrm{ng} / \mathrm{g} \mathrm{DM}$ and $0.009 \pm 0.007 \mathrm{ng} / \mathrm{g} \mathrm{DM}$, respectively.

\section{Real Time PCR analysis}

PCB104 and PCB153 treatment had no significant effect on the expression of all tested genes: VEGF-A $_{120}$, VEGF-A ${ }_{164}$, Flt-1 and KDR (Fig. 2) in comparison with the control group.

A

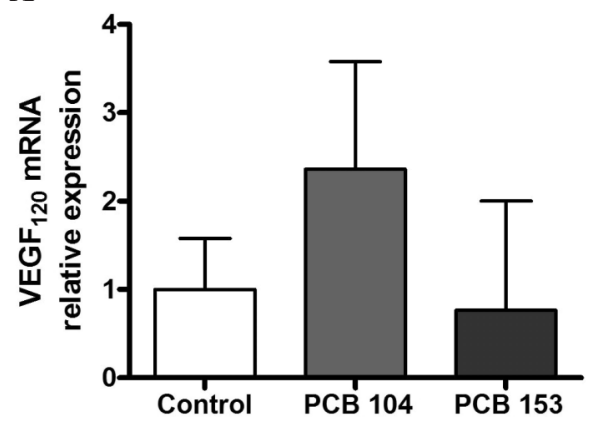

C

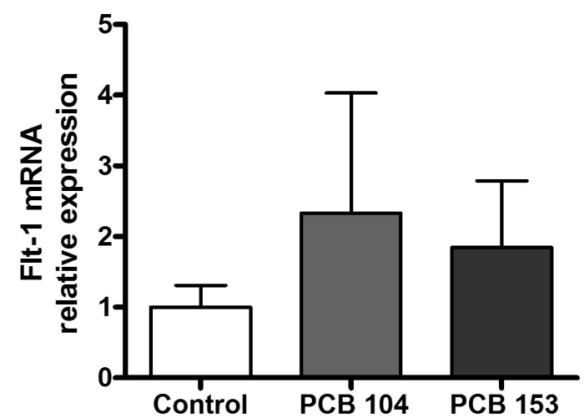

PCB153 action was compared with that of PCB104, formerly documented as affecting the VEGF system in vitro (Eum et al. 2004). Neither PCB153 nor PCB104 exposure significantly altered the mRNA of the VEGF-receptor system expression in the CP in ovariectomized adult sheep. The high variability of PCB concentration $(78.5 \%$ for PCB104 and $21.8 \%$ for PCB153) observed in our study may account for large individual differences in $\mathrm{PCB}$ action on VEGF-receptor system mRNA expression. An earlier study demonstrated that maternal exposure to low doses $(98 \mu \mathrm{g} / \mathrm{kg} \mathrm{bw})$ of PCB153 during gestation and lactation suppressed prepubertal plasma $\mathrm{LH}$ concentrations, delayed the onset of puberty of the female offspring, altered bone composition, and suppressed neonatal immunity in goats (Lyche et al. 2004a, b, Lyche et al. 2006, Lundberg et al. 2006). Recently we observed symptoms of estrogenization (enlarged vulva and edematous uterus) in PCB153 treated ewes, in which the plasma concentration of PCB153 was $196 \mathrm{pg} / \mathrm{ml}$, equivalent to $2.4 \mathrm{ng} / \mathrm{g}$ DM

B

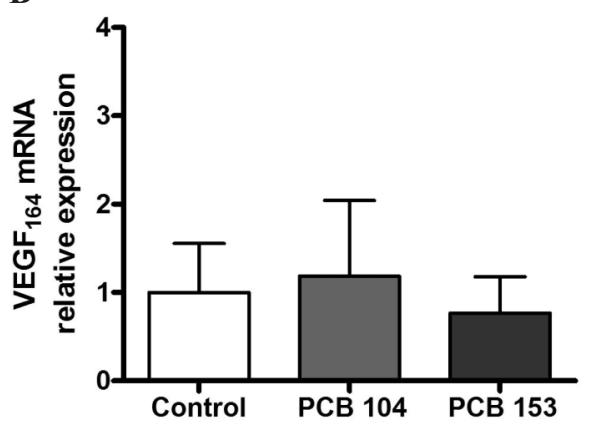

D

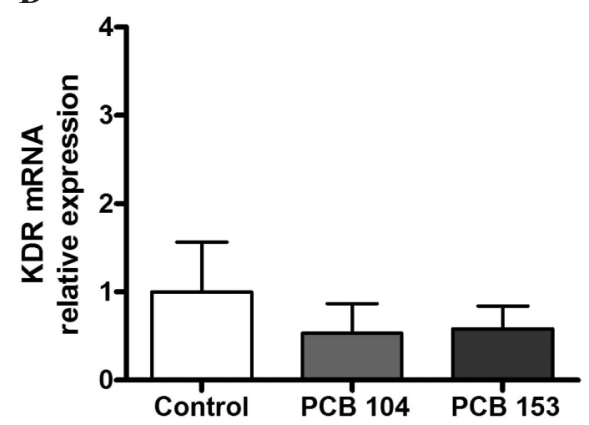

Fig. 2. Effect of PCB104 and PCB153 on mRNA expression of VEGF120 (A), VEGF164 (B), and its receptors Flt-1 (C) and KDR (D) in the choroid plexuses of adult ovariectomized sheep. Results were normalized to control group receiving vehicle (control) which was considered as $100 \%$.

\section{Discussion}

This is the first study investigating the effect of environmentally relevant PCB153 in vivo on the VEGF-receptor system in the CP. In this study
(Skipor et al. 2012). Moreover, in these sheep basal plasma LH and pulsatile LH release was also affected (Skipor et al. 2012). It should be noted that the mean plasma concentration of PCB153 found in our study (1.4 ng/g DM, corresponding to $0.116 \mathrm{ng} / \mathrm{ml}$ ) as well 
as in our earlier study $(0.196 \mathrm{ng} / \mathrm{ml})$ is similar to the PCB153 concentration measured in the human population in the United States (http://www.cdc.gov/exposurereport). According to a national report on human exposure to environmental chemicals, the geometric mean of serum PCB153 concentration in humans was $0.167 \mathrm{ng} / \mathrm{g}(0.151-0.185 \mathrm{ng} / \mathrm{g}$, 95\% confidence interval, CI) in $2001-2002$ and $0.121 \mathrm{ng} / \mathrm{ml}(0.114-0.128 \mathrm{ng} / \mathrm{ml}$, 95\% CI) in 2003-2004.

In constrast to PCB153, PCB104 is not environmentally and tissue relevant (http://www.ewg.org/reports/bodyburden2, Fielden et al. 1997), mainly due to the low distribution in commercial PCB mixtures (Frame 1997). In our studies, treatment of ewes with a low dose of PCB104 increased its concentration in blood plasma from an undetectable level to $0.009 \mathrm{ng} / \mathrm{g}$ DM (corresponding to $0.75 \mathrm{pg} / \mathrm{ml}$ ). In humans, measurement of PCB104 in umbilical blood plasma gave $0.9 \mathrm{pg} / \mathrm{g}$ of lipid weight, corresponding approximately to $0.007 \mathrm{pg} / \mathrm{ml} \mathrm{(http://www.ewg.org/reports/}$ bodyburden2). Therefore, we demonstrated here that a 100 times higher concentration of PCB104 than those found in humans did not affect the VEGF-receptor system in the CP. The dose of PCB104 used in in vitro studies promoting an increase in the microvascular permeability and the transmigration of breast cancer cells following PCB104 treatment ranged from 2-15 $\mu \mathrm{M}$, which corresponds to $650-4860 \mathrm{ng} / \mathrm{ml}$. Such high concentrations of total PCBs $(3-6 \mu \mathrm{M})$ were detected in human blood plasma in industrialized areas of the Netherlands and in the Aland/Turku Archipelago (Koopman-Esseboom et al. 1994, Hagmar et al. 1998).

In our studies, treatment of ewes with the same low doses $(0.1 \mathrm{mg} / \mathrm{kg}$ bw) of PCB104 and PCB153 resulted in about 150 times higher concentration of PCB153 in blood plasma compared to PCB104. This could result from feeding ewes with hay containing PCB153 since the concentrations of PCB153 congener in hay is among the highest compared to other congeners (Chauhan et al. 2000). Costera et al. (2006) showed that amounts of PCB153 in hay may reach 460 $\mathrm{ng} / \mathrm{kg} / \mathrm{DM}$. It is also possible that our findings may result from the lower resistance to the biotransformation for PCB104 than for PCB153, which was demonstrated to be very resistant (Thomas et al. 1999). Indeed, about $22 \%$ of the total PCB residue in human tissue consists of PCB153 (Jensen and Sundstrom 1974). It has been suggested that binding of PCB with transthyretin in blood plasma protects against their rapid removal from circulation. PCB153 binds with transthyretin more effectively than PCB104 (IC50, 90 vs. >1000) (Chauhan et al. 2000). In our study, the mean concentration of PCB153 in blood plasma was about $1.4 \mathrm{ng} / \mathrm{ml}$. This is below the levels measured in the plasma of pregnant goats $(30 \mathrm{ng} / \mathrm{g}$ wet weight) long-term treated with a similar dose of PCB153 (Lyche et al. 2004b). Such discrepancy between two closely related animal families could be due to species difference, as differences in reactivity to PCB treatment has also been reported between rats and mice (Craft at al. 2002). Alternatively, it could stem from the use of pregnant goats by Lyche et al. (2004b) and ovariectomized sheep in our study. Finally, the endocrine status of the female rather than a difference in regimen of the treatment may be responsible for such a discrepancy, since we demonstrated that in sheep two-week oral administration of low doses of PCB153 $(0.3 \mathrm{mg} / \mathrm{kg} \mathrm{bw})$ induced higher levels of PCB153 in short days than long days (Skipor et al. 2012).

In summary we demonstrated that increase of plasma PCB153 concentration to the level present in humans and PCB104 concentration to the level exceeding 100 fold that present in human plasma did not affect the VEGF-receptor system in the CP in adult ewes.

\section{Acknowledgement}

This work was supported by the Polish Ministry of Science and Higher Education and Grant 258/N-INRA/2008/0 and DWM/N19/INRA/2008.

\section{References}

Body burden - the pollution in newborns. A benchmark investigation of industrial chemicals pollutants and pesticides in umbilical cord blood. In Environmental Working Group (2005). http://www.ewg.org/reports/bodyburden2/ testresults.php.

Chauhan KR, Kodavanti PR, McKinney JD (2000) Assessing the role of ortho-substitution on polychlorinated biphenyl binding to transthyretin, a thyroxine transport protein. Toxicol Appl Pharmacol 162: 10-21.

Choi W, Eum SY, Lee YW, Hennig B, Robertson LW, Toborek M (2003) PCB 104-induced proinflammatory reactions in human vascular endothelial cells: relationship to cancer metastasis and atherogenesis. Toxicol Sci 75: 47-56.

Costera A, Feldt C, Marchand P, Le Bizec B, Rychen G (2006) PCDD/F and PCB transfer to milk in goats exposed to a long-term intake of contaminated hay. Chemosphere 64: 650-657.

Craft ES, DeVito MJ, Crofton KM (2002) Comparative responsiveness of hypothyroxinemia and hepatic enzyme induction in long-Evans rats versus $\mathrm{C} 57 \mathrm{BL} / 6 \mathrm{~J}$ mice exposed to TCDD-like and phenobarbital-like polychlorinated biphenyl congeners. Toxicol Sci 68: 372-380.

Drouilhet L, Taragnat C, Fontaine J, Duittoz A, Mulsant P, Bodin L, Fabre S (2010) Endocrine characterization of the reproductive axis in highly prolific lacaune sheep homozygous for the FecLL mutation. Biol Reprod 82: $815-824$. 
Eum SY, Andras IE, Couraud PO, Hennig B, Toborek $\mathrm{M}$ (2008) $\mathrm{PCB}$ and tight junction expression. Environ Toxicol Pharmacol 25: 234-240.

Eum SY, Lee YW, Hennig B, Toborek M (2004) VEGF regulates $\mathrm{PCB}$ 104-mediated stimulation of permeability and transmigration of breast cancer cells in human microvascular endothelial cells. Exp Cell Res 296: 231-244.

Esser S, Wolburg K, Wolburg H, Breier G, Kurzchalia T, Risau W (1998) Vascular endothelial growth factor induces endothelial fenestrations in vitro. $J$ Cell Biol 140: 947-959.

Faroon O, Jones D, de Rosa C (2001) Effects of polychlorinated biphenyls on the nervous system. Toxicol Ind Health 16: 305-333.

Fielden MR, Chen I, Chittim B, Safe SH, Zacharewski TR (1997) Examination of the estrogenicity of 2,4,6,2',6'-pentachlorobiphenyl (PCB 104), its hydroxylated metabolite 2,4,6,2',6'-pentachloro-4-biphenylol (HO-PCB 104), and a further chlorinated derivative, 2,4,6,2',4',6'-hexachlorobiphenyl (PCB 155). Environ Health Perspect 105: 1238-1248.

Fourth national report on human exposure to environmental chemicals (2009) The Fourth Report, http://www.cdc.gov/exposurereport, pp. 352-353.

Frame GM (1997) A collaborative study of 209 PCB congeners and 6 Aroclors on 20 different HRGC columns. Fresenius J Anal Chem 357: 701-713.

Hagmar L, Becher G, Heikkila A, Frankman O, Dyremark E, Schutz A, Ahlborg UG, Dybing E (1998) Consumption of fatty fish from the Baltic Sea and PCB in whole venous blood, plasma and cord blood from delivering women in the Aland/Turku Archipelago. J Toxicol Environ Health 53: 581-591.

Herman AP, Misztal T, Herman A, Tomaszewska-Zaremba D (2010) Expression of interleukin (IL)-1beta and IL-1 receptors genes in the hypothalamus of anoestrous ewes after lipopolysaccharide treatment. Reprod Domest Anim 45: 426-433.

Jensen S, Sundstrom G (1974) Structures and levels of most chlorobiphenyls in two technical PCB products and in human adipose tissue. Ambio 3: 70-76.

Kaczmarek MM, Blitek A, Kaminska K, Bodek G, Zygmunt M, Schams D, Zięcik AJ (2008) Assessment of VEGF-receptor system expression in the porcine endometrial stromal cells in response to insulin-like growth factor-I, ralaxin, oxytocin and prostaglandin E2. Mol Cell Endocrinol 291: 33-41.

Kodavanti PR, Ward TS, Derr-Yellin E, Mundy WR, Casey AC, Bush B, Tilson HA (1998) Congener-specific distribution of polychlorinated biphenyls in brain regions, blood, liver, and fat of adult rats following repeated exposure to Aroclor 1254. Toxicol Appl Pharmacol 153: $199-210$.

Koopman-Esseboom C, Huisman M, Weisglas-Kuperus N, Boersma ER, de Ridder MA, Van der Paauw CG, Tuinstra LG, Sauer PJ (1994) Dioxin and PCB levels in blood and human milk in relation to living areas in The Netherlands. Chemosphere 29: 2327-2338.

Lundberg R, Lyche JL, Ropstad E, Aleksandersen M, Rönn M, Skaare JU, Larsson S, Orberg J, Lind PM (2006) Perinatal exposure to PCB 153, but not PCB 126, alters bone tissue composition in female goat offspring. Toxicology 228: 33-40.
Lyche JL, Larsen HJ, Skaare JU, Tverdal A, Johansen GM, Ropstad E (2006) Perinatal exposure to low doses of PCB 153 and PCB 126 affects maternal and neonatal immunity in goat kids. J Toxicol Environ Health A 69: $139-158$.

Lyche JL, Oskam IC, Skaare JU, Reksen O, Sweeney T, Dahl E, Farstad W, Ropstad E (2004a) Effects of gestational and lactational exposure to low doses of PCBs 126 and 153 on anterior pituitary and gonadal hormones and on puberty in female goats. Reprod Toxicol 19: 87-95.

Lyche JL, Skaare JU, Larsen HJ, Ropstad E (2004b) Levels of PCB 126 and PCB 153 in plasma and tissues in goats exposed during gestation and lactation. Chemosphere 55: 621-629.

Maharaj AS, Walshe TE, Saint-Geniez M, Venkatesha S, Maldonado AE, Himes NC, Matharu KS, Karumanchi SA, D'Amore PA (2008) VEGF and TGF- $\beta$ are required for the maintenance of choroid plexus and ependyma. J Exp Med 205: 491-501.

Montie EW, Reddy CM, Gebbink WA, Touhey KE, Hahn ME, Letcher RJ (2009) Organohalogen contaminants and metabolites in cerebrospinal fluid and cerebellum gray matter in short-beaked common dolphins and Atlantic white-sided dolphins from the western North Atlantic. Environ Pollut 157: 2345-2358.

Nico B, Mangieri D, Corsi P, De Giorgis M, Vacca A, Roncali L, Ribatti D (2004) Vascular endothelial growth factor-A, vascular endothelial growth factor receptor-2 and angiopoietin-2 expression in the mouse choroid plexuses. Brain Res 1013: 256-259.

Oskam IC, Lyche JL, Krogenaes A, Thomassen R, Skaare JU, Wiger R, Dahl E, Sweeney T, Stien A, Ropstad $\mathrm{E}$ (2005) Effects of long-term maternal exposure to low doses of PCB126 and PCB153 on the reproductive system and related hormones of young male goats. Reproduction 130: 731-742.

Redmer DA, Aitken RP, Milne JS, Reynolds LP, Wallace JM (2005) Influence of maternal nutrition on messenger RNA expression of placental angiogenic factors and their receptors at midgestation in adolescent sheep. Biol Reprod 72: 1004-1009.

Roberts WG, Palade GE (1995) Increased microvascular permeability and endothelial fenestrations induced by vascular endothelial growth factor. J Cell Sci 108: 2369-2379.

Safe SH (1994) Polychlorinated biphenyls (PCBs): environmental impact, biochemical and toxic responses, and implications for risk assessment. Crit Rev Toxicol 24: 87-149.

Seelbach M, Chen L, Powell A, Choi YJ, Zhang B, Hennig B, Toborek M (2010) Polychlorinated biphenyls disrupt blood-brain barrier integrity and promote brain metastasis formation. Environ Health Perspect 118: 479-484.

Sipka S, Eum SY, Son KW, Xu S, Gavalas VG, Hennig B, Toborek M (2008) Oral administration of PCBs induces proinflamatory and prometasstatic responses. Environ Toxicol Pharmacol 25: 251-259.

Skipor J, Młynarczuk J, Szczepkowska A, Lagaraine C, Grochowalski A, Guillaume D, Dufourny L, Thiery JC (2012) Photoperiod modulates access of 2,2',4,4', 5,5'-hexachlorobiphenyl (PCB153) to the brain and its effect on gonadotropin and thyroid hormones in adult ewes. Ecotoxicol Environ Saf 78: 336-343. 
Skipor J, Thiery JC (2008) The choroid plexus-cerebrospinal fluid system: undervaluated pathway of neuroendocrine signaling into the brain. Acta Neurobiol Exp 68: 414-428.

Surma-Zadora M, Grochowalski A (2008) Using a membrane technique (SPM) for high-fat food sample preparation in the determination of chlorinated persistent organic pollutants by a GC/ECD method. Food Chem 111: $230-235$.

Szczepkowska A, Wąsowska B, Gilun PD, Lagaraine C, Robert V, Dufourny L, Thiéry JC Skipor J (2012) Pattern of expression of vascular endothelial growth factor and its receptors in the ovine choroid plexus during long and short photoperiods. Cell Tissue Res 350: 157-166.

Takasuga T, Senthilkumar K, Watanabe K, Takemori H, Shoda T, Kuroda Y (2004) Ultratrace analysis of polychloronated biphenyls (PCBs) and their hydroxylated metabolites (OH-PCBs) in human serum and cerebrospinal fluid (CSF) samples. Organohalogen Compounds 66: 2529-2534.
Thomas GO, Sweetman AJ, Jones KC (1999) PCBs in dairy cows - metabolism and body-burden. Organohalogen Compounds 41: 459-462.

Vonnahme KA, Redmer DA, Borowczyk E, Bilski JJ, Luther JS, Johnson ML, Reynolds LP, Grazul-Bilska AT (2006) Vascular composition, apoptosis, and expression of angiogenic factors in the corpus luteum during prostaglandin F2alpha-induced regression in sheep. Reproduction 131: 1115-1126.

Witmer AN, Dai J, Weich HA, Vrensen GF, Schlingemann RO (2002) Expression of vascular endothelial growth factor receptors 1, 2, and 3 in quiescent endothelia. J Histochem Cytochem 50: 767-777.

Yang J, Dombrowski SM, Deshpande A, Krajcir N, Luciano MG (2010) VEGF/VEGFR-2 changes in frontal cortex, choroid plexus, and CSF after chronic obstructive hydrocephalus. J Neurol Sci 296: 39-46.

Zhao S, Fernald RD (2005) Comprehensive algorithm for quantitative real-time polymerase chain rReaction. J Comput Biol 12: 1047-1064. 